\title{
Effect of Moisture Content on the Behavior of High Strength Concrete at High Temperatures
}

\section{Efeito do Teor de Umidade no Comportamento do Concreto de Alta Resistência em Altas Temperaturas}

\author{
Larissa Degliuomini Kirchhof ${ }^{1}$, Rogério Cattelan Antocheves de Lima ${ }^{1}$, \\ Almir Barros da Silva Santos Neto ${ }^{1}$, Alana Costa Quispe ${ }^{1}$ \\ Luiz Carlos Pinto da Silva Filho ${ }^{2}$
}

\footnotetext{
${ }^{1}$ Programa de Pós-Graduação em Engenharia Civil (PPGEC) - Universidade Federal de Santa Maria (UFSM). Santa Maria, RS, Brasil.e-mail: larissadk@gmail.com, antocheves@gmail.com, almir.neto@ufsm.br, alanacostaquispe@gmail.com

${ }^{2}$ Programa de Pós-Graduação em Engenharia Civil (PPGEC) - Universidade Federal do Rio Grande do Sul (UFRGS), Porto Alegre, RS, Brasil. E-mail: lcarlos66@gmail.com
}

\begin{abstract}
In this paper, an experimental program was carried out to investigate the residual mechanical properties of high strength concrete and normal strength concrete, and how moisture content and temperature affect the spalling process. Three mixtures with water-cementitious material ratios, from 0.25 to 0.50 , and with different saturation levels were heated in an electric furnace to elevated temperatures, from $200^{\circ} \mathrm{C}$ to $600^{\circ} \mathrm{C}$. After heating, the specimens were cooled down to room temperature and then tested for compression and tensile strength. The results showed that high moisture content induces the spalling process and reduces considerably the mechanical properties of high strength concrete, mainly at temperatures above $400^{\circ} \mathrm{C}$.
\end{abstract}

Keywords: high temperature, fire, concrete, moisture, spalling.

\section{RESUMO}

Neste trabalho, foi realizado um programa experimental para investigar as propriedades mecânicas residuais dos concretos de alta resistência e de resistência normal, além de como o teor de umidade e a temperatura afetam o desplacamento explosivo. Três misturas com relação água-materiais cimentícios, de 0,25 à 0,50 , e com diferentes níveis de saturação foram aquecidas em forno elétrico à temperaturas elevadas, de $200^{\circ} \mathrm{C}$ à $600^{\circ} \mathrm{C}$. Após o aquecimento, as amostras foram resfriadas à temperatura ambiente e depois ensaiadas quanto à resistência à compressão e à tração. Os resultados mostraram que altos teores de umidade induzem o desplacamento explosivo e reduzem consideravelmente as propriedades mecânicas do concreto de alta resistência, principalmente em temperaturas acima de $400^{\circ} \mathrm{C}$.

Palavras-chave: altas temperaturas, fogo, concreto, umidade, desplacamento explosive.

\section{INTRODUCTION}

In recent years, the construction industry has shown significant interest in the use of High Strength Concrete (HSC), whereas it offers significant economic and architectural advantages over the Normal Strength Concrete (NSC), among being suited for special construction requiring high durability [1]. These advances result from improvements in the material internal microstructure given by several factors, such as: modifications in the mixture composition, water-reduction admixtures, the use of superplasticizers, optimization of grain size distribution, the use of particles with pozzolanic activity, fibers addition, etc. [2-3]. However, in cases where HSC is exposed to fire attack, the refinement of the pore structure seems to contribute negatively to its fire resistance, rendering the material more susceptible to explosive spalling.

Explosive spalling is considered a concrete catastrophic failure, that generally occurs during the early 
stages of fire, when concrete reaches temperatures up to $300^{\circ} \mathrm{C}$ [4]. The material explosively brakes into pieces, often without advance notice [5]. This phenomenon is strongly related to the initial pore saturation and moisture migration in concrete. When the temperature increases, the free water in the pores will expand, while increasing the saturated vapor pressure. The continuous expansion of water, together with the moisture migration, frequently leads to a physical saturation of the pores. Further heating will then generate additional strains in the pores and can lead to cracking and hydraulic fracture of the solid skeleton [6]. A review of the literature indicates that explosive spalling is a result of a combination of two effects: the build-up of pore pressure by vaporization and moisture transport and thermal stresses and external loads in concrete [3, 7-10].

It is a consensus that there is a number of factors that influences the explosive concrete spalling such as moisture content, porosity, strength, type of aggregate, heating rate, applied loads, constraints and others. The interaction among these different factors and how they influence each other are not completely understood and can cause differences on the results [7]. According with [11], these differences can be attributed to the non-homegeneity of concrete which gives each concrete specimen a unique material structure with unique voids and moisture distribution.

HSC particularly is more susceptible to this phenomenon because of the low porosity/permeability and high percentage of initial pore saturation/moisture content [5-7, 12-15].

Data from specific studies show this dependency. Fire tests conducted in concrete slabs with various moisture contents and different classes of concrete showed that moisture content has a dominant influence on spalling frequency for concrete strengths greater than $60 \mathrm{MPa}$ [16]. A similar research was conducted by [17] in a series of fire damage degree tests in concrete slabs with $90 \%$ of moisture content. The results showed the cover loss of concrete due to spalling and consequently the exposition of aggregates to fire. [18] reported that a lower $\mathrm{w} / \mathrm{b}$ at the beginning of mixing and/or a higher moisture content at the time when concrete is exposed to high temperature is prone to induce spalling of concrete as a result of the increased pore vapor pressure.

It can be found an estimation of a level of moisture content under which spalling is unlikely to occur in [19]. The recommended value is $3 \%$ by weight. However, according with [20], a potencial problem with the fixed 3\% moisture limit is that other factors are excluded, such as the type of aggregate, porosity, permeability and amount of cement in the mix rate. These factors can reduce the precision in the setting of this type of limit. In fact, [21] reported that HSC mixes without fibers, with moisture content by weight from $3,8 \%$ to $5,2 \%$, did not show spalling during ISO 834 fire. However siliceous-calcareous concretes exhibited crater formed spalling on cylinder surface and all concretes cylinders with $60 \mathrm{~kg} / \mathrm{m}^{3}$ of silica fume (SF) showed severe explosive spalling with a max surface loss of $27 \%$ in the same moisture content conditions.

The addition of polypropylene (PP) fibers into HSC is a remarkable measure for preventing spalling [22-24]. [19] recommends to include more than $2 \mathrm{~kg} / \mathrm{m}^{3}$ of polypropylene fibers to prevent spalling in HSC, however the size of the fibers is not specified on the document. According with [25-27], PP fibers increase the permeability of concrete in consequence of melting at $170{ }^{\circ} \mathrm{C}$, contributing to the creation of a network more permeable than the matrix, allowing the outward migration of gas and resulting in the reduction of pore pressure. Also [18] explains that due to the melting and ignition of polypropylene, which is randomly distributed in concrete at a relatively low temperature, the left pores radiate out to form microcracks, connecting the existing capillary pores to provide channels for the scaping of water vapor.

High temperatures also affect the mechanical properties of HSC due to irreversible physical and chemical changes that happen in the material during the heating process [28,29]. Also, it was observed that the degree of deterioration in the properties was considerably worse if moisture was retained in the concrete during heating. Hence, the influence of heat exposure on the properties is critically dependent on the moisture content of concrete. However, there is a lack of information in the literature about the effect of moisture content on the properties of concrete at high temperatures. Data from [30] showed that the compressive strength is reduced substantially if moisture is kept inside the test sample. According with [31], there is a relationship between compressive strength and initial pore saturation after heating. A slight reduction in compressive strength was observed as the initial pore saturation increases, i.e., concrete specimens with higher moisture leads to a slightly lower strength. The authors attributed the strength loss to internal pressure effects in the pores. A similar analysis was performed by [32]. The results showed that the strength loss was higher in saturated samples $(40 \%)$ than dried samples $(15 \%)$ in the $150^{\circ} \mathrm{C}$ e $250^{\circ} \mathrm{C}$ range. [33] investigated the influence of temperature, water content, specimen size, strength grade and temperature profiles on the mechanical properties of normal-strength concrete (NSC) and high-strength concrete (HSC) after high temperature. The compressive strength of concrete after it was heated to $800^{\circ} \mathrm{C}$ was tested in three levels of water content: specimens heated to constant weight until $105^{\circ} \mathrm{C}$ before fire, ordinary specimens and specimens immerged into water for $48 \mathrm{~h}$ before fire. The results showed that different water content brings about different concrete 
compressive strength after high temperature. A slight reduction in compressive strength, independent of the grade of concrete, occurred in the specimens immerged into water for $48 \mathrm{~h}$ before fire. However, the authors concluded that the effect of water content on the compressive strength after $800^{\circ} \mathrm{C}$ was not remarkable.

In this paper, cylindrical specimens of three strength grades were submitted to high temperatures to investigate the effects of initial saturation and temperature on the residual mechanical properties of high strength concrete (HSC) and normal strength concrete (NSC), as well as to establish a relationship between compressive strength, saturation level and temperature associated with spalling occurrence.

\section{MATERIALS AND METHODS}

\subsection{Materials}

Portland cement used was equivalent to ASTM type V. Commercial silica fume was used as cementitious material. Crushed siliceous and natural river sand were used as coarse and fine aggregates, with nominal sizes of $19.0 \mathrm{~mm}$ and $4.8 \mathrm{~mm}$, respectively. For HSC specimens, a superplasticizer was used to achieve the required workability of concrete.

\subsection{Mix Proportions}

The study has been performed on 3 mixtures: two of High Strength Concrete (HSC) and one of Normal Strength Concrete (NSC). The mix proportions and the related 28-day concrete compressive strength are summarized in Table 1.

Table 1: Mix design for the normal-strength and high-performance concrete $\left(\mathrm{kg} / \mathrm{m}^{3}\right)$.

\begin{tabular}{l|c|c|c}
\hline \multirow{2}{*}{ Concrete mix } & \multicolumn{3}{c}{ Batch quantities $\left(\mathrm{kg} / \mathrm{m}^{3}\right)$} \\
\cline { 2 - 4 } & NSC & HSC-1 & HSC-2 \\
\hline Ordinary Portland cement & 367 & 493 & 520 \\
\hline Silica fume & - & 49 & 52 \\
\hline Coarse aggregate $(19.0 \mathrm{~mm})$ & 1083 & 1118 & 1136 \\
\hline Sand $(4.8 \mathrm{~mm})$ & 716 & 634 & 628 \\
\hline Water & 183.5 & 150 & 140 \\
\hline Superplasticizer & - & 2.46 & 4.27 \\
\hline $\mathrm{f}_{\text {c28days }}(\mathrm{MPa})$ & 43.2 & 77.8 & 85.8 \\
\hline
\end{tabular}

\subsection{Curing and Sample Preparation}

The specimens were demolded 24 hours after casting and placed in a water tank at room temperature at least for 28 days. At this age, 3 samples of each concrete mix batch were removed from the tank and their saturated weights were determined. Afterwards, the samples were placed in a furnace and dried at $105^{\circ} \mathrm{C}$ until a constant dry weight was reached. Dry and saturated weights were used as reference data for the determination of the saturation levels in the concrete specimens. Three different saturation percentages were selected for this study: $75 \%, 90 \%$ and $100 \%$. During the drying process of the specimens reaching the saturation degree of $75 \%$ and $90 \%$, the $100 \%$ saturated samples were maintained in the water tank, so that all the samples were tested with the same age (90 days). When the specimens reached the targeted saturation levels, they were sealed in metallic packages and placed in a climatic chamber to retain the saturation level until the heating test was carried out.

\subsection{Heating Regime}

A total number of 56 groups of three cylindrical specimens were heated in an electric furnace up to $200^{\circ} \mathrm{C}$, $400^{\circ} \mathrm{C}$ and $600^{\circ} \mathrm{C}$ (target temperatures). The furnace temperature was set by a digital temperature controller connected to the furnace power supply, with temperature feedback from a thermocouple located in the furnace. The specimens were heated without pre-load until reaching the target temperature and maintained until a thermal steady state was achieved (2 hours). After exposure, the furnace was switched off and the specimens were allowed to cool down for 24 hours inside the furnace. Then, the specimens were removed from the furnace and allowed to cool naturally to room temperature. The results were compared with reference values at room temperature (unheated concrete specimens). 


\section{RESULTS AND DISCUSSION}

\subsection{Residual Compressive Strength}

The effects of moisture content on the compressive strength of high strength concretes at elevated temperatures are shown in Figure 1 . At $200^{\circ} \mathrm{C}$, a small improvement occurred in the residual strength, which varies from 3 to $12 \%$. This is consistent with what has been observed by others investigations [34-36]. In [34], the recovery of strength in unstressed specimens occurred between 200 and $300^{\circ} \mathrm{C}$ and it was attributed to the general stiffening of the cement gel or to the increase in surface forces between gel particles due to the removal of adsorbed moisture. In [37], it was suggested that the strength increase could be a slow process of hydration stimulated by the temperature. Finally, [38] emphasized that the increase of strength can be happening because the concrete was exposed to high temperatures at an early age. On the other hand, within the $200-400^{\circ} \mathrm{C}$ range, the strength loss was markedly different between the HSC grades. While HSC-1 samples lost strength above $400^{\circ} \mathrm{C}$, HSC-2 samples still experienced a strength increase for the saturation levels of $75 \%$ and $90 \%$. In the literature, this behavior has only been observed in stressed tests $[13-15,34]$ and may be related to the higher intrinsic strength of HSC-2 or to the fact that the confined water retards the material thermal degradation. At $600^{\circ} \mathrm{C}$, HSC specimens showed a reduction in compressive strength. [39] reported that the strength loss at the this temperature is attributed to decomposition of calcium hydroxide between 450 and $500^{\circ} \mathrm{C}$. Besides, saturated samples showed the lower residual strength due to the occurrence of spalling in 50\% of the HSC saturated samples, affecting considerably their compressive strength. Finally, it can be noted a relationship between compressive strength, saturation level and spalling frequency at $600^{\circ} \mathrm{C}$. The probability of spalling on HSC increases as the saturation level and compressive strength of the material also increases.
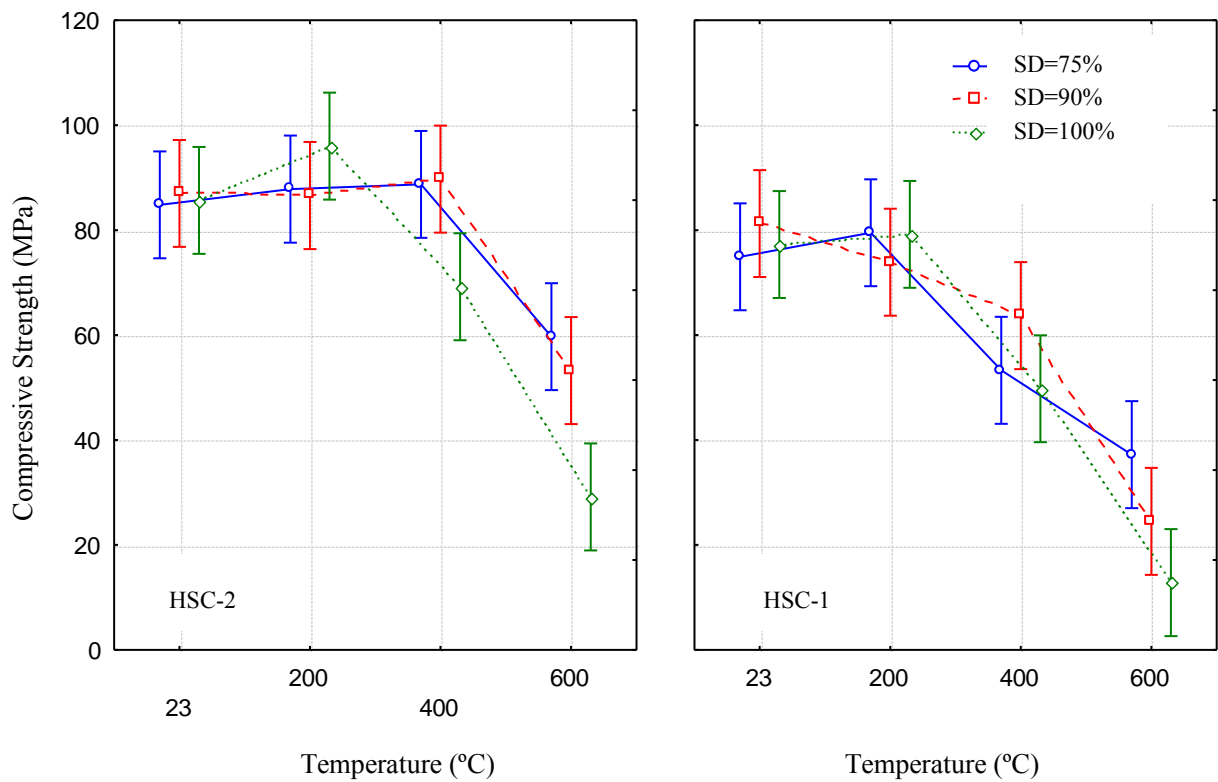

Figure 1: Influence of Saturation Degree (SD) on compression strength of HSC at elevated temperatures.

Since spalling of NSC samples under heating was not noticed (even for saturated specimens), the strength results are only compared with HSC saturated specimens, as shown in Figure 2. By comparison, it has been found that the compressive strength in NSC diminishes gradually with the increase of temperature, while in $\mathrm{HSC}$ samples the strength loss is more pronounced only within the $400-600^{\circ} \mathrm{C}$ range. The reduction factors for compressive strength of NSC and HSC are given in Table 2. 


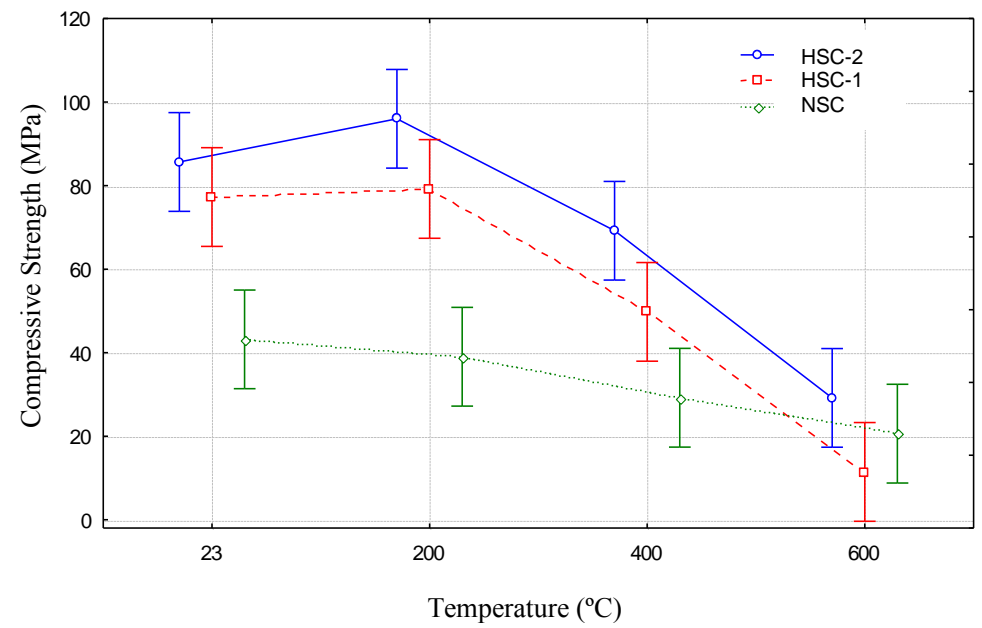

Figure 2: Influence of temperature on compressive strength of NSC and HSC specimens at the saturation condition.

Table 2: Reduction factors for compressive strength of NSC and HSC saturated samples.

\begin{tabular}{c|c|c|c}
\hline \multirow{2}{*}{ Temperature $\left({ }^{\circ} \mathrm{C}\right)$} & \multicolumn{3}{|c}{$\mathrm{k}_{\mathrm{c}, \theta}=\mathrm{f}_{\mathrm{c}, \theta} / \mathrm{f}_{\mathrm{c}, 23^{\circ} \mathrm{C}}$} \\
\cline { 2 - 4 } & NSC & HSC-1 & HSC-2 \\
\hline 23 & 1,00 & 1,00 & 1,00 \\
\hline 200 & 0,90 & 1,03 & 1,12 \\
\hline 400 & 0,68 & 0,64 & 0,81 \\
\hline 600 & 0,48 & 0,17 & 0,34 \\
\hline
\end{tabular}

\subsection{Residual Tensile Strength}

The experimental results concerning the effects of moisture content and temperature on HSC tensile strength are shown in Figure 3. Both HSC grades have similar behavior for all the saturation levels. At first, at $200^{\circ} \mathrm{C}$, it seems that the saturated samples have retained more strength than the unsaturated specimens. This may be due to the evaporation of free water, which retards the thermal deterioration of the material. However, within the $200-400^{\circ} \mathrm{C}$ range, the strength reduction of saturated samples is higher than unsaturated specimens. This might happen because of the lower strength loss of saturated samples between $23^{\circ} \mathrm{C}$ and $200^{\circ} \mathrm{C}$. At last, at $600^{\circ} \mathrm{C}$, the water content presents a significant role in concrete tensile strength, where saturated samples showed the lower residual strength due to $50 \%$ of the samples suffered spalling, affecting drastically the tensile behavior of HSC. [40] reported that at this level of temperature the severe strength loss is attributed not only to the decomposition of the hydration products but also the thermal incompatibility between aggregates and cement paste. For HSC, [33] observed that the dense structure induces thermal stress that results in many microcracks and even a few macrocracks. Besides, the decomposition of $\mathrm{Ca}(\mathrm{OH})_{2}$ and other components also induce the appearance of cracks. 

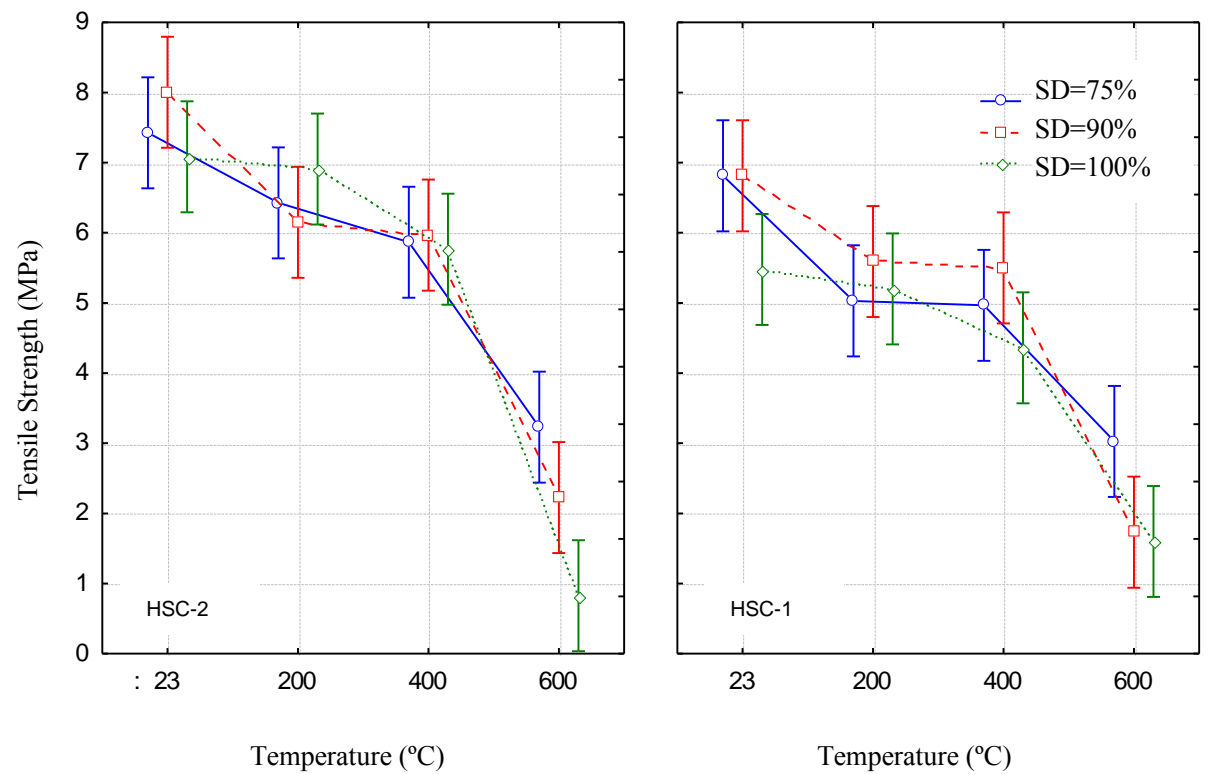

Figure 3: Influence of Saturation Degree (SD) on tensile strength of HSC at elevated temperatures.

By comparison, Figure 4 shows the tensile behavior of HSC and NSC at high temperatures for saturated specimens. Again, NSC and HSC behave differently at high temperatures. The tensile strength in NSC diminishes linearly with the increase of temperature. However, HSC maintains a higher percentage value of residual strength up to $400^{\circ} \mathrm{C}$, followed by a sharp reduction at $600^{\circ} \mathrm{C}$. The reduction factors for tensile strength of NSC and HSC are given in Table 3.

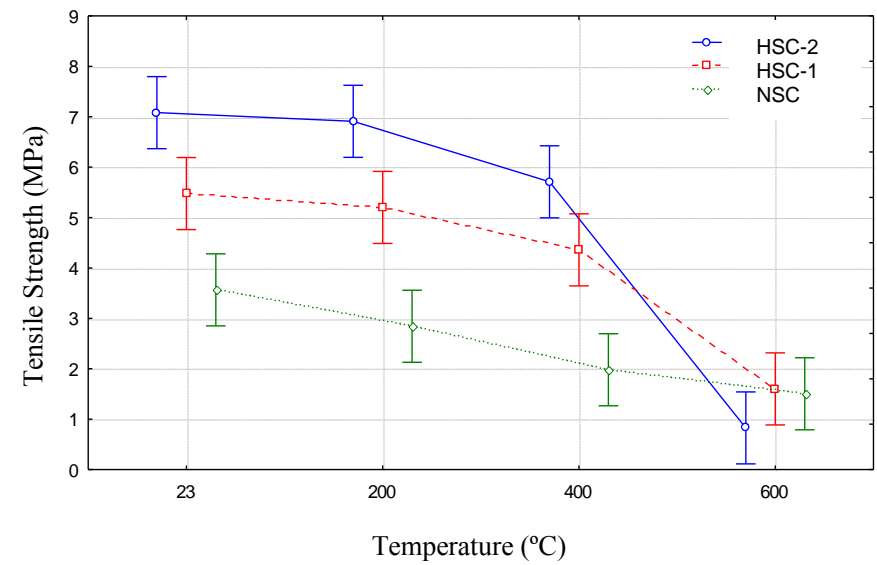

Figure 4: Influence of temperature on tensile strength of NSC and HSC specimens at the saturation condition.

Table 3: Reduction factors for tensile strength of NSC and HSC saturated samples.

\begin{tabular}{c|c|c|c}
\hline \multirow{2}{*}{ Temperature $\left({ }^{\circ} \mathrm{C}\right)$} & \multicolumn{3}{|c}{$\mathrm{k}_{\mathrm{t}, \theta}=\mathrm{f}_{\mathrm{t}, \theta} / \mathrm{f}_{\mathrm{t}, 23^{\circ} \mathrm{C}}$} \\
\cline { 2 - 4 } & NSC & HSC-1 & HSC-2 \\
\hline 23 & 1,00 & 1,00 & 1,00 \\
\hline 200 & 0,80 & 0,95 & 0,98 \\
\hline 400 & 0,55 & 0,79 & 0,81 \\
\hline 600 & 0,42 & 0,29 & 0,12 \\
\hline
\end{tabular}

Table 4 shows that the influence of temperature on tensile strength is more pronounced than the compressive strength. The results were obtained considering the average of all the saturation degrees $(75 \%, 90 \%$ and $100 \%)$. According with [41], this behavior might be related to the occurrence of many micro- or macro- 
cracks in the specimens, due to thermal incompatibility within the heated concrete. Tensile strength seems to be more sensitive to such cracks than the compressive strength. In conformity to [42], tensile strength reduction is a result mainly related to the thermal composition and/or the stability of the formed hydrates, which act as the main binders between the concrete constituents.

Table 4: Comparison between reduction factors for compressive and tensile strength of HSC.

\begin{tabular}{c|c|c}
\hline Temperature $\left({ }^{\circ} \mathrm{C}\right)$ & $\mathrm{k}_{\mathrm{c}, \theta}=\mathrm{f}_{\mathrm{c}, \theta} / \mathrm{f}_{\mathrm{c}, 23^{\circ} \mathrm{C}}$ & $\mathrm{k}_{\mathrm{t}, \theta}=\mathrm{f}_{\mathrm{t}, \theta} / \mathrm{f}_{\mathrm{t}, 23^{\circ} \mathrm{C}}$ \\
\hline 23 & 1,00 & 1,00 \\
\hline 200 & 1,03 & 0,85 \\
\hline 400 & 0,84 & 0,77 \\
\hline 600 & 0,46 & 0,35 \\
\hline
\end{tabular}

\section{CONCLUSIONS}

In this study, the effects of moisture content on the residual properties of different concrete grades exposed to high temperatures were investigated. The results assessment provides interesting conclusions:

- Normal strength concretes and high strength concretes behave differently when exposed to high temperatures. In NSC, the reduction of mechanical properties happens gradually with the increase of temperature, while in HSC a considerable loss of strength starts from $400^{\circ} \mathrm{C}$;

- The saturation level affects considerably the residual strength of high strength concretes at elevated temperatures, mainly in the $400-600^{\circ} \mathrm{C}$ range, due to damages caused by chemical and physical changes in the microstructure, together with the spalling process;

- The strength reduction on tensile strength is higher than compressive strength since tensile strength is more susceptible to the development of cracks with the increase of temperature;

- Explosive spalling did not occur in the NSC specimens, even for saturated samples. This behavior can be attributed to the connectivity of pores which can allow the water vapor to escape, avoiding vapor pressure build-up in the pores. However, in the HSC specimens, the spalling frequency is mainly associated to the saturation level and the compressive strength of the material. As the moisture content in concretes with low porosity/permeability increases, the probability of spalling occurrence also increases.

\section{ACKNOWLEDGEMENTS}

Financial support from CNPq (sponsorship) is acknowledged. This work was undertaken within the Civil Engineering Department at Federal University of Rio Grande do Sul - Brazil.

\section{BIBLIOGRAPHY}

[1] PHAN, L.P., CARINO, N.J., "Review of mechanical properties of HSC at elevated temperatures", Journal of Materials in Civil Engineering, v. 19, n.6, pp. 58-64, 1998.

[2] AITCIN, P.C., High-Performance Concrete. E \& FN Spon, London,UK., 1998.

[3] KALIFA P., MENNETEAU, F.D., QUENARD, D., "Spalling and pore pressure in HPC at high temperature”, Cement and Concrete Research, v. 30 n. 12, pp. 1915-1927, 2000.

[4] KHOURY, G.A., ANDERBERG, Y. "Concrete spalling review”, Report submitted to the Swedish National Road Administration, 60 p., 2000.

[5] KODUR, V.K.R. "Spalling in high strength concrete exposed to fire - Concerns, causes, critical parameters and cures", Structures, v. 103, pp. 180-188, 2000.

[6] KHOYLOU, N., ENGLAND, G., "The effect of elevated temperatures on the moisture migration and spalling behavior of high-strength and normal concretes", ACI Materials Journal, SP, v. 167, pp. 263-289, 1997.

[7] KHOURY, G.A. "Effect of fire on concrete and concrete structures", Prog. Struct. Eng. Mater., v. 2, n. 4, pp. 429-447, 2000. 
[8] SULLIVAN, P.J.E; ZAMAN, A.A.A. "Explosive spalling of concrete exposed to high temperature", In: Proceedings of International Conference on Structural Mechanics in Reactor Technology, Berlin, 4H, 105$18,1971$.

[9] ULM, F.J., ACKER, P., LEVY, M. "The Chunnel fire II: Analysis of concrete damage”, Journal of Engineering Mechanics, v. 125, pp. 283-289, 1999.

[10] DWAIKAT, M.D., KODUR, V.K.R. "Hydrothermal Model for Predicting Fire-induced Spalling in Concrete Structural Systems", Fire Safety Journal, v. 44, pp. 425-434, 2009.

[11] ALI, F., ALI, N., SILCOCK, G., et al., "Outcomes of a major research on fire resistance of concrete columns", Fire Safety Journal, v. 39, pp. 103-116, 2004.

[12] PHAN, L.T. "Fire performance of high-strength concrete: A report of the State-of-the-art", In: National Institute of Standards and Technology, Gaitherburg, MD., 1996.

[13] BAZANT, Z.P.; KAPLAN, M.F. Concrete at high temperatures - Material properties and Mathematical Models, Longman Group Limited, England, 1996.

[14] SULLIVAN, P.J.E., "A probabilistic method of testing for the assessment of deterioration and explosive spalling of high strength concrete beams in flexure at high temperature", Cement \& Concrete Composites, v. 26, n.2, pp. 155-162, 2004.

[15] HERTZ, H.D., "Limits of spalling of fire exposed concrete". Fire Safety Journal, v. 38, n.2, pp. 103116,2003

[16] CHAN, S.Y.N., PENG, G-F., ANSON, M. "Fire behavior of high-performance concrete made with silica fume at various moisture contents", ACI Materials Journal, v. 96, n. 3, pp. 405-411, 1999.

[17] WANG, R, YAN, Q., TIAN, B., et al., "Effect of Moisture Content and Fiber on the High-Temperature Properties of Tunnel Second Lining Concrete", Journal of Highway and Transportation Research and Development, v. 9, n.3, pp. 63-68, 2015.

[18] MA, Q., GUO, R., ZHAO, Z., et al., "Mechanical properties of concrete at high temperature - A review", Construction and Building Materials, v. 93, pp. 371-383, 2015.

[19] Eurocode 2: "Design of concrete structures - Part 1-2: General rules - Structural fire design", Brussels, Belgium, 2004.

[20] JANSSON, R. "Fire Spalling of Concrete: Theoretical and Experimental Studies", Ph.D. Thesis, KTH Royal Institute of Technology, 2013.

[21] YERMAK, N., PLIYA, P., BEAUCOUR, A-L., et al., "Influence of steel and /or polypropylene fibers on the behavior of concrete at high temperature: Spalling, transfer and mechanical properties", Construction and Building Materials, v. 132, pp. 240-250, 2017.

[22] MORITA, T., NISHIDA, A., YAMASAKI, N., et al., "An experimental study on spalling of high strength concrete elements under fire attack", Fire Safety Science - Proceedings of the Sixth International Symposium, France, pp. 855-866, 1999.

[23] AKCA, A.H., ZIHNIOGLU, N.O. "High performance concrete under elevated temperatures", Construction and Building Materials, v. 44, pp. 317-328, 2013.

[24] SIDERIS, K.K.; MANITA, P. "Residual mechanical characteristics and spalling resistance of fiber reinforced self-compacting concretes exposed to elevated temperatures", Construction and building Materials, v. 41, pp. 296-302, 2013.

[25] KALIFA, P., CHÉNÉ, G., GALLÉ, C. "High temperature behaviour of HPC with polypropylene fibres from spalling to microstructure", Cement and Concrete Research, v. 31, n.10, pp. 1487-1499, 2001.

[26] KOMONEN, J. PENTALLA, V. "Effects of high temperature on the pore structure and strength of plain and polypropylene fiber reinforced cement pastes", Fire Technology, v. 39, pp. 3-34, 2003.

[27] TAKANO, T., et al., "Residual properties of high strength fiber reinforced concrete exposed to high temperature", In: Third International Conference of Concrete under Severe Conditions (CONSEC'01), Proceedings... Vancouver, University of British Columbia, 2V, v.1, pp. 473-479, Canada, 2001.

[28] SHORT, N.R., PURKISS, J.A., GUISE, S.E. “Assessment of Fire Damaged Concrete Using Colour Image Analysis", Construction and Building Materials, v. 15, pp. 9-15, 2001.

[29] GEORGALI, B.; TSAKIRIDIS, P.E. "Microstructure of fire-damaged concrete. A case study", Cement \& Concrete Composites, v. 27, pp. 225-259, 2005. 
[30] LANKARD, D.R., BIRKIMER, D.L., FONDRIEST, F.F., et al., "Effect of moisture content on the structural properties of Portland cement concrete exposed to temperatures up to 500 F", ACI Materials Journal, SP, v.25, pp. 59-102, 1971.

[31] LAU, A., ANSON, M. "Effect of high temperatures on high performance steel fibre reinforced concrete", Cement and Concrete Research, 36, n. 9, pp. 1698-1707, 2006.

[32] SHAH, S.P., AHMAD, S.H. High Performance Concrete: Properties and Applications, MCgraw-HILL, 1994.

[33] LI, M., QIAN, C., SUN, W. "Mechanical properties of high-strength concrete after fire", Cement and Concrete Research, v. 34, n.6, pp. 1001-1005, 2004.

[34] CASTILLO, C., DURRANI, A.J. "Effect of transient high temperature on high-strength concrete", $A C I$ Materials Journal, v. 87, n.1, pp. 47-53, 1990.

[35] HOOF, G., BILODEAU, A., MALHOTRA, V.M. "Elevated temperature effects on HSC residual strength", Concrete International, v. 22, n.4, pp. 41-47, 2000.

[36] PHAN, L.T.; CARINO, N.J. "Effects of test conditions and mixture proportions on behavior of highstrength concrete exposed to high temperatures", ACI Materials Journal, v. 99, n.1, pp. 54-66, 2002.

[37] LIMA, R.C.A. Investigation of concrete behavior in high temperatures, (in Portuguese), Thesis, Porto Alegre, Brazil, 2005.

[38] NEVILLE, A.M. Properties of Concrete, (in Portuguese), Ed. Pini, 2 ed. São Paulo, 2016.

[39] BENTZ, D.P. "Fibers, percolation and spalling of high-performance concrete", Materials Journal, v.97 n.3, pp. 351-359, 2000.

[40] BEHNOOD, A., GHANDEHARI, M. "Comparison of compressive and splitting tensile strength of high - strength concrete with and without polypropylene fibers heated to high temperatures", Fire Safety Journal, v. 44, pp. 1015-1022, 2009.

[41] MEHTA, P.K., MONTEIRO, P.J.M. "Microstructure, properties and materials", McGraw-Hill Companies, USA, 2010.

[42] SAAD, M., ABO-EL-ENEIN, S.A., HANNA, G.B., et al., "Effect of temperature on physical and mechanical properties of concrete containing silica fume", Cement and Concrete Research, v.26, n.5, pp. 669675,2001

\section{ORCID}

Larissa Degliuomini Kirchhof Rogério Cattelan Antocheves de Lima Almir Barros da Silva Santos Neto Alana Costa Quispe Luiz Carlos Pinto da Silva Filho https://orcid.org/0000-0003-4775-2181

https://orcid.org/0000-0001-6622-2210

https://orcid.org/0000-0001-7306-5313

https://orcid.org/0000-0001-9138-2873

https://orcid.org/0000-0003-3703-7328 